This item is the archived peer-reviewed author-version of:

Reinier de Graaf : Four walls and a roof. The complex nature of a simple profession

\title{
Reference:
}

Schrijver Lara.- Reinier de Graaf : Four w alls and a roof. The complex nature of a simple profession

Journal of architecture - ISSN 1360-2365 - Abingdon, Routledge journals, taylor \& francis Itd, 23:7-8(2018), p. 1321-1328

Full text (Publisher's DOI): https://doi.org/10.1080/13602365.2018.1514772

To cite this reference: https://hdl.handle.net/10067/1546580151162165141 


\section{Four Walls and a Roof. The complex nature of a simple profession}

By Reinier de Graaf

Cambridge, Mass., Harvard University Press, 2017 ISBN: 9780674976108

Hb., pp. 528, 70 b/w ills

$\$ 35.00 / £ 25.95$

\section{From holy ground to middle ground: the complex nature of architecture} Lara Schrijver

Two decades into the $21^{\text {st }}$ century, the architecture debate is notably diverse and self-reflective, encompassing urgent societal issues such as the environmental impact of the building industry (widely known to be a big contributor to the global carbon footprint), the transformation of the countryside, and emerging explorations of other manners to be an architect, to name but a few current strands. ${ }^{1}$ In an era defined by major global concerns, extensive urbanization and the rapid development of technologies throughout all spheres of life, it might be somewhat surprising to see the central drive of architecture boiled back down to 'four walls and a roof'. This ostensibly 'simple profession' is, however, a complex system of interdependencies, which this book to some extent helps unpack. Written by Reinier de Graaf, partner of OMA and head of AMO, Four Walls and a Roof is situated in the contemporary architecture debate, yet also sits against the foil of the so-called 'Superdutch' generation (and the broader period when architects became starchitects), as well as an earlier legacy of modernist architecture and its hope to improve society through its buildings. The book is simultaneously ambitious in its scope, and modest in its statements. It takes on a plethora of societal issues, yet also tones down the potential impact that any single architect, or firm, may have had. The field seems to have grown tired of signature architecture, yet a clear alternative is not yet at hand.

To some degree, this fatigue may be related to the complicated constellation of traits attributed to buildings, including functional requirements, ethical appeals, aesthetic conventions and underlying symbolic gestures. Buildings have hereby become placeholders for issues far outside the realm of design and construction. This history of a certain hubris is a longstanding one, which can be demonstrably traced back to the earliest known treatise on architecture, around $27 \mathrm{BCE}$. In his Ten Books on Architecture, Vitruvius positions architecture as the 'mother of the Arts', noting that

since this study is so vast in extent, embellished and enriched as it is with many different kinds of learning, I think that men have no right to profess themselves architects hastily, without having climbed from boyhood the steps of these studies and thus, nursed by the knowledge of many arts and sciences, having reached the heights of the holy ground of architecture. (book I ch.11)

Treating architecture as 'holy ground' contributes to the systematic overestimation of what a building can, or should, accomplish that marks the first half of the twentieth century. Yet even in a time when architecture is often seen as increasingly irrelevant, and the social aspirations of modern architecture no 
longer tenable, the profession's self-image as potentially changing the world seems difficult to shake. ${ }^{2}$ A book such as this, addressing both the myths and the realities of a changing profession, is a welcome addition to the debate. As head of AMO, the research branch of OMA, author Reinier de Graaf is well-placed to address the many faces of a profession that is - to quote founding principal Rem Koolhaas-'a hazardous mixture of omnipotence and impotence'. ${ }^{3}$ In the essays, which began in 2014 with an opinion piece in Dezeen, De Graaf faces this legacy of modernism that was (too) strongly convinced of its ability to transform society head-on, supporting the intention to improve living conditions and address societal concerns, yet acknowledging the limitations of the profession as well. ${ }^{4}$

The book takes the reader through various twists and turns of practicing architecture in the contemporary global world, providing 'snapshots of a world usually invisible to outsiders.' (p. xi). Beneath these cameos of practice lie two main storylines, which centre on the internal concerns of the profession (what can architecture do?) and the external conditions it is situated in. In this dual perspective, De Graaf's strength is the ability to address acute concerns about the current historical moment from the tangible perspective of the architect's workplace. For example, broad concerns about the accumulation of capital with a small and exclusive group of people becomes tangible when we realize houses no longer primarily serve as shelter, but as investment. Overall, seven sections form the framework of the book, each taking on a particular 'myth looming over the profession of architecture: its presumed authority (Part I), its reliance on individual inspiration (Part II), its commitment to good causes (Part III), its control of its own professional practices (Part IV), its independence from external powers (Part V), its mastery of the large scale (Part VI), and, finally, its unrelenting devotion to progress (Part VII).' (p. xi). Sections such as 'Authority', 'Default by Design' and 'Megalopoli(tic)s', provide a framework for the various types of reflection and anecdotal observations and build up to an overall pondering of the state of the profession and the society it serves. This combination of larger framework and individual examples serves to address the many forces from within and without that determine our built environment, while remaining situated within a longer tradition of self-reflection in architecture. In this manner, the book seeks to contribute to a robust body of knowledge, both addressing the topical contingencies of a particular practice, and reflecting them against timeless issues in architecture.

Most striking perhaps is the contemplative undertone, which to some degree comes from a dryness that drives home his pointed observations, but which is also a manner of refraining from judgment-mistaken by some for cynicism and a dismissal of societal engagement. ${ }^{5}$ However, I would suggest this restraint is driven more by De Graaf's desire to understand the world in which he works: 'My recommendation is that architects become more aware of the context in which they work and take more time to look around at the world that asks them to do what they do so that they can for instance recognise the motives behind it.' 6 This is what resonates throughout his reflections on both the nature of the global practice of OMA/AMO and the contemporary societal conditions that shape it. As such, this book provides a refreshing style after the final years of the twentieth 
century, a period that Diane Ghirardo identified as 'three decades of theoretical delirium in which poeticising reflection passed for theory ... thirty years of trying on and discarding borrowed theories with all the rapidity of a commodified consumer at an outlet sale'.7 De Graaf's document may not lay out the building blocks and principles of architecture in the manner of the classical treatises we are familiar with, but it does reflect on what it means to practice architecture today, as well as examining the results of architecture's many good intentions.

As such, the book presents an array of types and models through which architecture continues to hone its vocabulary in response to a continually changing context. Each new model is then also more productive than in the definition of Quatremère de Quincy, who sees the model as constrained by a formal similarity, producing nothing new. ${ }^{8}$ Instead, in De Graaf's approach, even the particularity and formal definition of a model (as opposed to a more generic and abstracted type) provides a new ground for experimentation. For example, an essay on East German housing discusses not only the internal workings of the profession but also the often-unintended consequences of its idealism over time. Ruminating on the legacy of the GDR, he describes the traditional family homes that are being constructed out of prefab concrete panels recycled from the original Plattenbau complexes, housing blocks from the bygone socialist era. Here, a mode of housing construction that was seen to express a specific ideology shows how its very elements are equally adaptable to an archetypal diagram of the house ('four walls and a roof'): 'Far from becoming obsolete, the concrete WBS 70 panels prove intrinsically tougher than the political system that begat them, and now operate as a finite, almost wholly recyclable resource in the context of the market economy.' (p.49)

In 'Bloody Fools!', De Graaf shows sympathy for the Pimlico School project by John Bancroft, complete in 1970 and demolished in 2010. Describing the school, he makes note of how this large concrete and glass building nevertheless has ' $\mathrm{a}$ kind of humility' due to its sunken ground level. He describes the origins of the building as part of the Greater London Council plans for modernizing London, which included numerous institutional buildings such as this large school. Having outlived its purpose, and as a building seen to have 'perceived design faults [that] impair the building's architectural value,' it is slated for demolition despite Bancroft's efforts to prevent this, along with other admirers of the Brutalist buildings. Here, the building stands as an example of how 'the essence of a city can be encapsulated in a single building or, more precisely, in the fate that the city bestows on that building.' De Graaf presents this particular case as 'the definitive end of a short-lived, fragile period of naïve optimism before the brutal rule of the market economy became the common denominator.' (p.27)

Not everything in the book is so serious: 'Trial and Error' (section IV) in particular provides behind-the-scenes journal-type entries with juicy stories that satisfy those looking for a hint of the glamour of OMA. Reflecting on a politically sensitive commission in Russia that plays out during the transition from Medvedev to Putin, De Graaf describes a phone call with his client: 'we hear sirens in the background. In the middle of our phone call, he quickly apologizes and hangs up.' (p.269). Some stories may well encourage young architects to 
think twice about their aspirations: after the office put in many hours of work for a competition invitation, they discovered that it was merely a ruse to oust the mayor. The building was never meant to be realized, showing how architecture remains a plaything of those in power: all the ambitions of modernist architecture were (and are still) dependent on a client willing to build them. The European welfare state may have provided a strong legacy of public commissions, in most parts of the world, architecture is still mainly for the privileged few.

This may in part explain the notably ambivalent perspective De Graaf holds on the responsibility of the architect. The approach to projects documented in the book both reflects the drive to build, and yet contains a scepticism. This in itself is not surprising for OMA, but becomes beautifully tangible in some of the examples. Describing a Russian commission for a science campus deferred in favour of a ski resort, he notes that afterwards 'the same client is requesting another science campus, based on the same design principles but designed for a different location [...] We decline.' (p.205) This does raise the question of whether this is the last vestige of the architect's autonomy: is refusing a commission the limit of the architect's power in the $21^{\text {st }}$ century? What will that mean in the long run?

Throughout, De Graaf demonstrates his ability to turn challenges into valuable insights, reflecting on the many dependencies that architecture engages with. He describes near-coincidental commissions, and the manner in which a presentation deemed undesirable is edited out: 'our refusal to remove slides from our presentation has led to the removal of our presentation as a whole. As we watch the online footage, it is as though we were never there' (p.265). The practice of architecture is in many ways challenging: beyond the immediately obvious need for a client and a budget, there are negotiations with contractors, differing professional habits in different places, developments in regulations and changing insights on environmental impact. Some of these conditions have led architects to explore alternative modes of practice. ${ }^{9}$ This additionally raises a question for architecture schools: are the exercises that go into forming architects sufficient as a foundational course to critical engagement with society's spatial desires, or should we be introducing entirely other skills in the curriculum to prepare them for alternative careers? In any event, it appears that a more sustained reflection is necessary on what constitutes the core knowledge of the profession, and which skills are crucial to the future careers of aspiring architects.

Throughout history, the architect has been seen as having fundamental authority, thanks to both extensive studies and a presumed monopoly of (artistic) genius. Yet this book suggests something different: that the architect might be more adequately characterized as a Wizard of $\mathrm{Oz}-$ a figure ruling over a realm with smoke and mirrors, projecting a strong persona to hide the fact that this figure is only a human (and a small one at that). The contrast between the mythical persona of the architect and the humbler positioning here is enormous, and raises a question: could it simply be that, over the course of 2000 years, the profession itself has been diminished? Or has it transformed so deeply that we 
need to redefine the profession's raison d'être? Reading over De Graaf's experiences in London, Dubai and Moscow may be discouraging for the young architect, yet at the same time the book equally provides many moments of hope.

A substantial part of the underlying argument may be found in De Graaf's earlier work. In 2011, he curated the exhibition titled 'On Hold', held at the British School in Rome. Initially a way of examining the projects that were at the time postponed, the exhibition provided a way to study the mechanisms of practice. It is here that De Graaf first provided an analysis of OMA's projects that were then either on hold or indefinitely discontinued as a result of the global economic crisis of 2008, showing in ten projects how the architect remains dependent on external factors such as politics and economy. A subsequent exhibition De Graaf curated continued this interest in the hidden structures that determine a large part of our built environment: the AMO contribution to the 2014 Biennale presented work by the many unknown architects of city councils that determined the face of Europe in the postwar construction of the welfare state. ${ }^{10}$ In retrospect, this exhibition shows how even in 'anonymous' architecture, ideas about society becomes manifest in the built environment, while at the same time showing how particular building models are at times more robust than the ideas that gave rise to them in the first place. Overall, I would suggest that both exhibitions are precursors to the arguments in the book, showing how De Graaf has been steadily creating his own place in the architectural debate of today, exploring continuities and ideas in architecture through the filter of societal contingencies and their influence on practice.

The book develops the same logic further, extending it beyond the particular scope of postponed building commissions and the architecture of public works. De Graaf reports on the everyday life of the global architect, taking the reader from Venice to Moscow and Dubai and relating these contexts to suppositions we have about the practice of architecture in the $21^{\text {st }}$ century. As such, he seems to have developed a contemporary version of the reflective architect's essays of the late $19^{\text {th }}$ and early $20^{\text {th }}$ centuries, well before the age of Instagramable buildings and perhaps even before architecture was thought to be a viable alternative to revolution. Part cultural analysis, part sharp observation, part critical assessment of the profession, this book shows a developed, independent mind at work. The exhibitions, in particular, testify to De Graaf's independence in seeking out the cultural undercurrents that underpin his work as an architect.

The book's structure allows De Graaf to state his concerns about topical issues such as the uneven distribution of capital in a manner directly related to his work. In 'The Century that Never Happened' (pp. 415-426), he addresses social housing as a topic of growing concern with sharp cultural observations supporting Thomas Piketty's concerns on the accumulation of wealth with a small group of people. De Graaf notes that the aesthetic sobriety of modernism, originally intended to provide an adequate standard of living for the largest number of people, has led to an economy of construction that maximizes profit instead. He voices concern about the quality of the built environment as a result: 'When sale values exceed productions costs to the extent they now do, the quality of a building is no longer judged by its physical or aesthetic attributes but 
by its potential to sell for profit.' (p.422). Much as the Biennale exhibition 'Public Works' offered a new perspective on how we construct a perception of our society and its institutions through its built form, the book now offers thoughts on the state of this 'simple profession' today, and by extension the state of our society in general.

What remains after reading this book is a striking ensemble of scepticism towards the (mis)use of societal concerns, towards politics and towards the bureaucratic arrangements of values on the one hand, and an eminently hopeful tone, driven by what appears to be a conviction that one must do what one can that in fact the only way to fail is to stop trying. To this point, De Graaf seems to have found a mode of approaching each situation as is and seeking out the cracks and crevices within which some intervention might still be possible-as the making of rugs for a model presentation in Moscow demonstrate (p.217). Throughout, the quietly observational tone of the book might lead to misconceptions such as the accusation of cynicism. He notes: 'The focus on the importance of individual figures in architecture primarily masks architecture's failing as a collective', suggesting that he is not convinced about his own role. At the same time, the book documents the voice of an engaged architect who is deeply concerned about architecture's role in the diminishing field of individual (public) institutional commissions.

In general, De Graaf poses an interesting problem for architecture as a practice: in a time when the global market economy requires the architect to navigate multiple and oppositional political structures, how is it possible to construct a robust disciplinary knowledge and yet adapt to contingencies of city governance in widely diverse contexts? For De Graaf, the 1972 project 'City of the Captive Globe' captures something fundamental to this era in its pluralism: what he calls 'the agreement to disagree'. The project remains a strong metaphor, presenting the Manhattan grid as an ordering system that allows multiple utopias to coexist. In the contemporary age, this is no trivial insight, similar to the discourse on type that allows for an abstracted logic that is both adaptable and (weakly) related to form, enabling general ideas to adapt to particular contexts and times.

As we now begin to formulate a more modest understanding of what architecture may bring to societal concerns, issues focusing on historically robust notions, such as the discourse on 'type', may aid in delineating the agency and limitations of architecture in its societal role. ${ }^{11}$ While this understanding of 'type' is not central to De Graaf's argument, his balancing act between what one might consider archetypal concerns of architecture as a discipline and their ability to influence societal structures may aid in this venture.

Would it then be fair to place De Graaf at the centre of a repositioning of architecture? One that tones down its mythical register, yet continues to stubbornly try to improve the world? This book at least shows a promising way forward, both sweeping and modest. An architect who, within this limited circle of influence, continues to seek the possibility to reclaim the societal role of architecture beyond its iconographic gestures of the late twentieth century. In the end, one thing that underpins De Graaf's book is a sense that architecture will 
never be entirely freed from its holy ground: the aspiration to better the world is part of its drive, and central to its ability to combine longstanding cultural discourses with current forms of experimentation. It may become a more robust profession if it embraces this duality, understanding that the architect in some sense needs to be both megalomaniacal to try, and humble to succeed.

\footnotetext{
${ }^{1}$ Blaine Brownell, 'Calculating the Ecological Footprint of the Built Environment', Architect Magazine, 26 October 2017, http://www.architectmagazine.com/practice/calculating-the-ecologicalfootprint-of-the-built-environment_o; In February 2018, the Federal Government Architect and Landscape Architect launched a competition on the transforming countryside in the Netherlands https://www.prijsvraagbroodenspelen.nl; Alyaa A. Younis, 'The Utopian Enterprise: Four Young Architects with a Social Mission', Huffington Post, 6 April, 2016 https://www.huffingtonpost.com/alyaa-a-younis/the-utopian-enterprisefo_b_9622806.html; Giovanna Borasi, The Other architect: Another Way of Building Architecture (Montreal: CCA, 2015).

2 'From this perspective, the socially engaged experiences of the twentieth century may prove to have been just a brief interlude in history's ongoing drama.' Jean-Louis Cohen, The Future of Architecture. Since 1889. (London: Phaidon, 2012): 474.

${ }^{3}$ Rem Koolhaas and Bruce Mau, 'Introduction', SMLXL (Rotterdam: 010 publishers, 1995), xix.

${ }^{4}$ Reinier de Graaf, "The vast majority of the built environment is of an unspeakable ugliness', Dezeen, 10 december, 2014. https://www.dezeen.com/2014/12/10/reinier-de-graaf-opinion-oma-the-builtenvironment-unspeakable-ugliness/

${ }^{5}$ Marina van den Bergen, 'Woorden en geen daden', Archined website, 30 november 2017, https://www.archined.nl/2017/11/woorden-en-geen-daden ${ }^{6}$ Mark Minkjan, interview with Reinier de Graaf, 'Architecture is in a state of denial', Failed Architecture, 6 december 2017.

https://failedarchitecture.com/reinier-de-graaf-architecture-is-in-a-state-ofdenial/

${ }^{7}$ Diane Ghirardo, 'Tafuri and Architectural Theory in the U.S., 1970-2000', Perspecta 33, Mining Autonomy (2002), 45.

${ }^{8}$ Antoine Chrysostôme Quatremère de Quincy, 'Type', in: K. Michael Hays, ed., Oppositions Reader: Selected Readings from a Journal for Ideas and Criticism in Architecture 1973-1984 (NY: Princeton Architectural Press, 1998 [orig. Paris, 1825]): 616-620.

9 Jeroen Visschers, 'Alles behalve een architectenbureau', 30 October 2017. https://www.archined.nl/2017/10/alles-behalve-een-architectenbureau

${ }^{10}$ Reinier de Graaf, curator, 'Public Works: Architecture by Civil Servants', exhibition for Venice Architecture Biennale 'Fundamentals', 2014.

11 Sam Jacoby (2015) Type versus typology Introduction, The Journal of Architecture, 20:6, 931-937.
} 